\title{
ベントナイトと砂との混合材の一次元的な 浸水変形特性
}

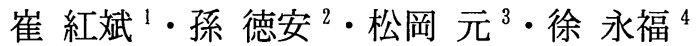 \\ 1 学生会員 工修 名古屋工業大学大学院 社会工学専攻(T466-8555 名古屋市昭和区御器所町) \\ Email:cui_hongbin@hotmail.com \\ ${ }^{2}$ 正会員 工博 名古屋工業大学大学院 社会工学専攻研究員 (T466-8555 名古屋市昭和区御器所町) \\ 3 フェロ一会員 工博 名古屋工業大学大学院 社会工学専攻教授 (T466-8555 名古屋市昭和区御器所町) \\ ${ }^{4}$ 工博 上海交通大学 建築工程与力学学院 (中国 200030 上海市崋山路 1954)
}

\begin{abstract}
単位乾燥体積当たりのモンモリロナイトの最大吸水量が一定であることに着目し, モンモリロナイト間隙 比という概念を用いて, 締固めたベントナイトと砂との混合材の浸水による膨潤変形とコラプス変形を統一 的に予測できることを示す. また, 低配合率の混合材においては, 砂の骨格間隙比がその砂の最大間隙比を 超えると砂粒子の間で接触が生じるため, 浸水終了後のモンモリロナイト間隙比と垂直圧の両対数紙上での 唯一的な直線関係 (状態線) を利用して浸水による変形量を予測するには適用できる垂直圧の範囲があるこ とがわかった. そこで, 砂の骨格間隙比を用いてこの適用応力範囲の予測法を提案・検証した.
\end{abstract}

Key Words: swelling, bentonite, montmorillonite, swelling pressure, skeleton void ratio

\section{1. はじめに}

高い膨潤特性と自己シール性を持つベントナイト は高レベル放射性核廃棄物の深地層処分において緩 衝材および埋め戻し材として使われることが期待さ れている。強度および締固め性能の向上のため砂と の混合材も検討の対象となっている ${ }^{1)}$.

膨潤性粘土であるベントナイトは浸水されると, 主成分であるモンモリロナイトが大きく膨らんで砂 粒子の間の間隙を埋め込むことができる，そのため ベントナイトと砂の混合材は非常に小さい透水係数 を示す ${ }^{2)}$ ．よく締固めたベントナイトと砂との混合 材は, 地下水の浸入により膨潤し, 周辺の岩盤に対 して膨潤圧を作用させることが予想される. また. 廃棄物の最終処分場でも遮水層として低配合率のべ ントナイトと砂などとの混合材を締固めて使ってい る. そこで, 膨潤性材料であるベントナイトと非膨 潤性材料である砂などの混合材が両材料の配合割合, 初期乾燥密度および浸水直前まで受けていた荷重に より, どんな浸水変形特性を示すのか, あるいはど れほどの膨潤圧を発生するのかを解明する必要があ る.

ベントナイトと砂との混合材の浸水膨潤変形特性
に関して，小峯・緒方 ${ }^{3)}$ は一次元下でモンモリロナ イトの膨潤体積ひずみと垂直圧との唯一的な関係が 成立することを明らかにし，この関係式に基づいて 浸水膨潤ひずみと膨潤圧を予測する方法を提案した. 一方, Mollins ${ }^{4)}$ は浸水終了後の水とベントナイト の体積の比と垂直圧の関係が各配合率の混合材によ って異なることも主張している.

本研究では, 締固めたベントナイトと砂との混合 材を対象に, 浸水による膨潤挙動だけでなく, 土粒 子間のサクションの解除による収縮挙動にも着目し, その変形挙動の解明を試みた。 また, 低配合率の混 合材においては, 砂粒子の接触により形成された骨 格が浸水変形挙動に及ぼす影響を検討している.

\section{2. 試験概要}

\section{(1) 試料}

本試験に用いた試料は, クニゲル $\mathrm{V} 1, \mathrm{Na}$ 型のベン トナイトと豊浦砂である. その物理特性 ${ }^{3)}$ を表- 1 に 示す. 図-1 のベントナイトの X 線回折図より,この種類 のベントナイトは, 膨潤性粘土釷物であるモンモリロナイ 卜と非膨潤性鉣物である長石, 方解石, 石英などで構成 
表-1＼cjkstart試料の物理特性

\begin{tabular}{|c|c|}
\hline $\begin{array}{c}\text { モンモリロナイトの乾燥密度 } \\
\left(\rho_{m}\right)\end{array}$ & $2.79 \mathrm{Mg} / \mathrm{m}^{3}$ \\
\hline $\begin{array}{c}\text { モンモリロナイト以外の鉱物の } \\
\text { 乾燥密度 }\left(\rho_{n m}\right)\end{array}$ & $2.79 \mathrm{Mg} / \mathrm{m}^{3}$ \\
\hline 豊浦砂の乾燥密度 $\left(\rho_{\text {sand }}\right)$ & $2.65 \mathrm{Mg} / \mathrm{m}^{3}$ \\
\hline ベントナイトの液性限界 & $473.9 \%$ \\
\hline ベントナイトの塑性限界 & $26.61 \%$ \\
\hline ベントナイトの塑性指数 & 447.3 \\
\hline モンモリロナイトの含有率 $(\beta)$ & $48 \%$ \\
\hline
\end{tabular}

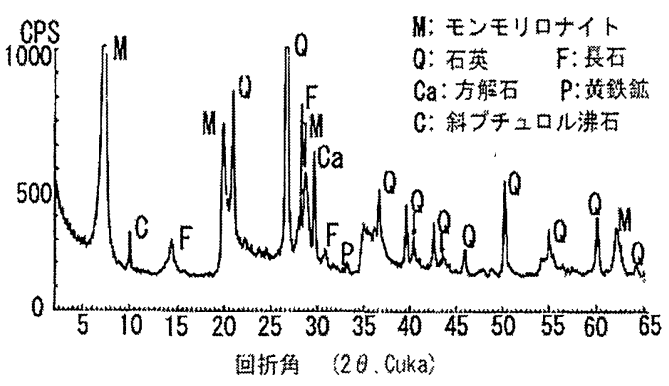

図-1 ベントナイトの $\mathrm{x}$ 線回折図

\section{されていることがわかる.}

混合材の試料は乾燥したベントナイトと砂を一定 の質量比で混ぜた後, 純水を加えて所定の含水比ま で調製した. 本研究ではベントナイトと砂との混合 材を対象とすることから, 配合率 $\alpha$ を用いてその 配合割合を示す. 配合率 $\alpha$ とは, ベントナイトの乾 燥質量が混合材全体の乾燥質量の中で占める割合を 示す. 式で示すと

$$
\alpha=M_{B} /\left(M_{B}+M_{\text {sand }}\right) \times 100
$$

ここに, $M_{B}$ と $M_{\text {sand }}$ はそれぞれベントナイトと砂の乾燥質 量である.

浸水試験では $100 \% ， 50 \% ， 30 \% ， 20 \% ， 17 \% ， 10 \%$ 全 部で 6 種類の配合率の混合材を用いた.

\section{（2）試験装置, 供試体および試験方法}

図-2 は本試験に用いた試験機の概要図を示す。こ の試験機は圧密リングの内径が $60 \mathrm{~mm}$, 高さが $20 \mathrm{~mm}$ である. ベントナイトは透水係数が非常に小さいこ とから, 浸水時間を短縮するため, 試験機に $500 \mathrm{~mm}$ ぐらいのビニル管をつけて, 給水する水頭の高さを 上げた.

浸水膨潤用の供試体の作製については，圧密リン

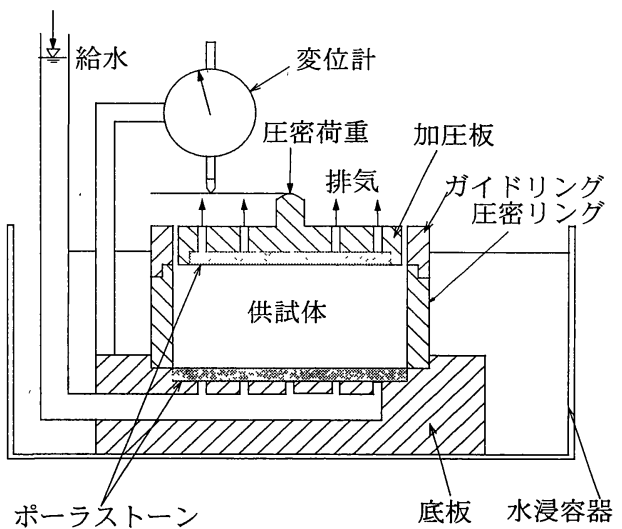

図-2＼cjkstart浸水試験に用いた標準圧密試験機

グにガイドリングを被せた後, 所定の質量の試料を 投入し, 直径 $60 \mathrm{~mm}$, 厚さ $10 \mathrm{~mm}, 7 \mathrm{~mm}, 5 \mathrm{~mm}$ の押し出し 円盤(鉄の塊)を 1 枚あるいは 2 枚を組み合わせて, 円盤が高さ $20 \mathrm{~mm}$ の圧密リングの中にちょうど入る までランマでたたきこんで成形させた. その後, 薄 い小刀で, 圧密リングの底の外部に露出した部分を 整形し, 重さを測り, 直径 $60 \mathrm{~mm}$, 高さ $3 \mathrm{~mm}, 5 \mathrm{~mm}, 10 \mathrm{~mm}$ および $13 \mathrm{~mm}$ の供試体を作製した．例えば，高さ $3 \mathrm{~mm}$ の供試体を作成するために, 厚さ $10 \mathrm{~mm}$ と $7 \mathrm{~mm}$ の円盤 を組み合わせて圧密リングの中にちょうど入るまで たたきこむ. そして，高さ $20-(10+7)=3 \mathrm{~mm}$ の供試体 が作成される. 供試体の高さを圧密リング高さ $20 \mathrm{~mm}$ より小さくしたのは, 小さい垂直圧で浸水すると大 きい膨潤変形を示すので, 膨潤する過程で圧密リン グよりはみ出すことを防ぐためである. また，大き い垂直圧では浸水によるひずみが小さいことから, 精度を高めるため供試体の高さを大きくした.

コラプス試験用の供試体は, 高さ $10 \mathrm{~mm}$ のガイド リングを高さ $20 \mathrm{~mm}$ の圧密リングに被せた後, 所定の 質量の試料を入れて, $10 \mathrm{~mm}$ の押し出し円盤がガイド リングの中にちょうど入るまでランマでたたきこん で高さ $20 \mathrm{~mm}$ の供試体を作製した.コラプス試験では 体積が圧縮されるため, 供試体の高さを大きくした.

試験は, 供試体を試験機にセットした後, ろ紙な どの圧縮を考慮して, まず $5 \mathrm{kPa}$ の垂直圧をかけて 1 時間ほど放置してから所定の垂直圧 $p$ まで段階的に 圧縮した. 給水は供試体の底部から行い, 給水する と同時にダイヤルゲージより垂直方向の変形量を計 測した. 浸水時間は供試体の初期状態によって異な り, 変形がほぼ落ち着く（配合率が $100 \%$ と $50 \%$ の場 合には大体 1 ケ月程度)まで給水を行った. ただし， コラプス試験では浸水による圧縮変形が約 3 日で終 了するが，水を十分吸収できるように浸水時間を長 
くした. 試験終了後の供試体の飽和度はほぼ $100 \%$ であった.

\section{3. 浸水終了後のモンモリロナイト間隚比 $e_{m}$ と 垂直圧 $p$ との唯一的な関係}

\section{（1）ベントナイトの浸水による膨潤・収粨挙動}

図-3 は, 配合率 $100 \%$ のベントナイトの供試体を 用いて, 初期状態から垂直圧 $p$ まで不飽和状態で圧 縮した後に浸水した場合, また, 浸水初期から膨潤 変形が生じないように垂直圧を調整しながら浸水し た場合の間隙比 $e$ と垂直圧 $p$ の関係を示す.

図-3 において，白抜きのプロット $(\bigcirc, \square, \triangle$, $\diamond)$ は, 初期乾燥密度 $\rho_{\mathrm{d} 0}=1.51 \mathrm{~g} / \mathrm{cm}^{3}$, 初期含水比 $w_{0}=21.6 \%$ のつの供試体に対して $40,80,160,640 \mathrm{kPa}$ までそれぞれ圧縮し，その後浸水した試験結果であ る. 半塗りのプロット (o) は初期乾燥密度 $\rho_{\mathrm{d} 0}=1.23$ $\mathrm{g} / \mathrm{cm}^{3}$, 初期含水比 $w_{0}=1.95 \%$ の供試体に対して, $2560 \mathrm{kPa}$ まで圧縮し, その後浸水した試験結果であ

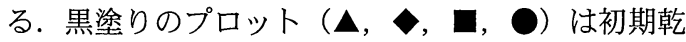
燥密度 $\rho_{\mathrm{d} 0}=0.86 \mathrm{~g} / \mathrm{cm}^{3}$, 初期含水比 $w_{0}=7.9 \%$ の 4 つの 供試体を用いて, 垂直圧 $p$ がそれぞれ 40, 80, 1280, $2560 \mathrm{kPa}$ になるまで圧縮し, その後浸水した試験結 果である.そして, 2 重丸と 2 重四角のプロット(○), 回）は,初期乾燥密度 $\rho_{\mathrm{d} 0}=0.86 \mathrm{~g} / \mathrm{cm}^{3}$, 初期含水比 $w_{0}=7.9 \%$ (回) 之初期乾燥密度 $\rho_{\mathrm{d} 0}=1.60 \mathrm{~g} / \mathrm{cm}^{3}$, 初期含 水比 $w_{0}=21.6 \%$ (○)の 2 つの供試体に対して行った 定体積浸水膨潤試験結果である.この試験では, 飽 和に至るまで圧密リング内の供試体を鉛直方向に変 形しないように垂直圧を調整する．そして，垂直圧 が安定したときの值を膨潤圧とする.

同図より, 浸水とともに膨潤挙動を示す供試体も あれば, 収縮挙動を示す供試体もあるのが見られる. 興味深いのは, 3 種類の初期状態の異なる供試体が 異なる垂直圧 $p$ のもとで浸水しても, 浸水終了後の 間隙比はほぼ一本の $\log _{e}-\log p$ 直線 (太い破線) 上に 乗ることである. 同図中の $40 \mathrm{kPa}$ と $80 \mathrm{kPa}$ ，および $2560 \mathrm{kPa}$ での試験結果より, 浸水直前の間隙比（あ るいは乾燥密度）が異なっても最終的にはほぼ同じ $\log e-\log p$ 直線まで変形するのが見られる. また, 定体積浸水膨潤試験より得られた膨潤圧と間隙比の 関係もこの線上にのることが見られる。

同図より，この直線の下の位置より浸水されると 膨潤挙動を示すが, 上の位置より浸水されると収縮 挙動を示すのがわかる. つまり, 図-3 中の太い破線 はベントナイトの浸水終了後の一種の状態線である と考えられる.

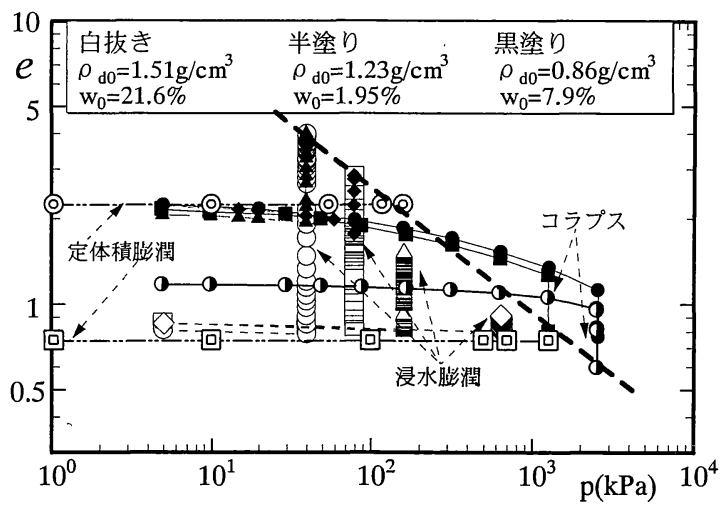

図-3 不飽和状態での圧縮と浸水による間隙比 の変化（ベントナイト : 砂 $=100: 0)$

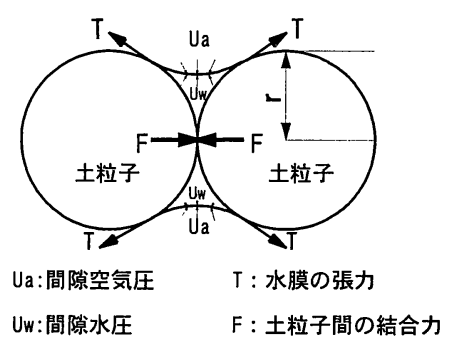

図-4 不飽和状態にある土粒子のモデル

\section{（2）ベントナイトの浸水による䞘潤あるいはコラプ スのメカニスム}

ベントナイトは膨潤性成分であるモンモリロナイ 卜を多く含んでいる. その膨潤機構 5), 6) としては, トランプのカードのような結晶構造を示すモンモリ ロナイトの層間の陽イオンと負の電荷を持つ双極子 である水分子が水和することにより，層間を押し広 げるためといわれている.

一方, 締固めたベントナイトのコラプス沈下挙動 に関する研究報告例はほとんど無く, そのメカニズ ムについてもはっきりした解釉がないようである. 非膨潤性粘土のコラプス現象のメカニズムについ ては, 多くの研究者 (例えば Barden ${ }^{7}$, Mitchell $^{8)}$ ) より解釈されているが，それらをまとめると次のよ うなものである. 図-4 に示すように, 不飽和土の土 粒子の間ではメニスカスが形成され, 負の間隙水圧 を有している（初期含水比が低い試料ほど負の間隙 水圧が大きく, Regina 粘土の場合, 初期含水比がほ ぼ 0\%の時に 650〜950MPa の大きなマトリックスサ クションが作用している ${ }^{9)}$ ). この負の間隙水圧の存 在により，土粒子の間に結合力 Fが生じる，結合力 F は土粒子の間のせん断抵抗を強める効果があり, 飽和土では構成できない構造をも形成（土粒子の間 


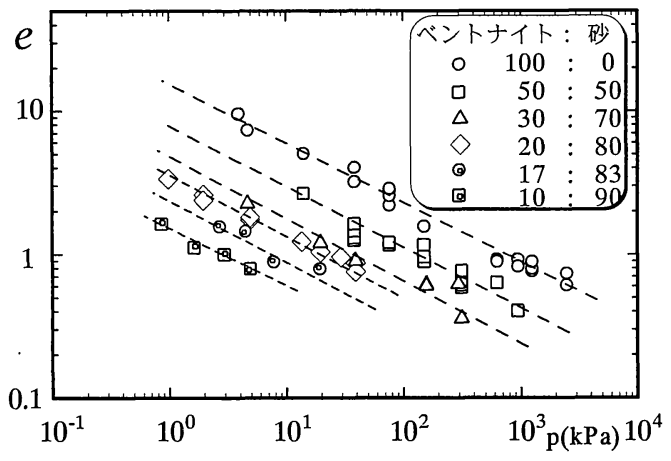

図-5 浸水終了後の混合材の間隙比亡垂直圧の関係

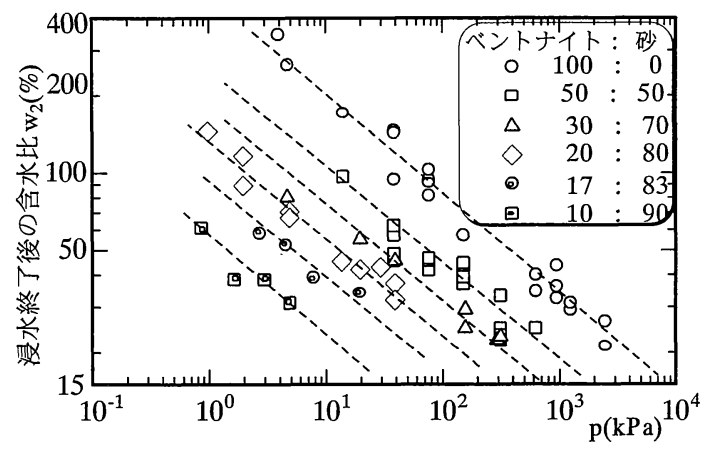

図-6 浸水終了後の含水比と垂直圧の関係

に大きな間隙が存在する）し，大きな載荷荷重に耐 えることができる. しかし, この構造は不安定であ るため, 大きな外部荷重を受けながら浸水すると, サクションの減少とともに構造が崩れてコラプス現 象を示すというものである.

膨潤性粘土であるベントナイトの場合は, 垂直圧 $p$ が膨潤圧より小さい範囲内で浸水すると, 浸水直 前の状態より膨潤する. 一方, 垂直圧が膨潤圧より 大きい場合は, 水を取り込んだモンモリロナイトが 膨潤すると同時に大きな間隙が崩れ, 結果的には収 縮挙動を示す.つまり,この場合はモンモリロナイ トの膨潤と, 大きな間隙の崩れが同時に発生すると 考えられる.ちなみに, 緩衝材や埋め戻し材が岩盤の クリープ変形や地質運動などで膨潤圧より大きい地 圧を受けながら浸水する場合には収縮挙動を示すと 予想される.

\section{（3）浸水終了後の $\log e-\log p$ 関係と $\log w-\log p$ 関係}

表-2 に浸水試験で用いた供試体の初期乾燥密度, 初期含水比と浸水する時の垂直圧の一覧を示す.

図-5 と図-6 は混合材において, 浸水終了後の間隙 比 $e$ と垂直圧 $p$ との関係, 浸水終了後の含水比 $w$ と 垂直圧 $p$ との関係を示す図面である.ただし，30\%, 表-2＼cjkstart浸水試験に用いた供試体の一覧

\begin{tabular}{|c|c|c|c|}
\hline 配合率 $(\%)$ & $\rho_{\mathrm{do}}\left(\mathrm{g} / \mathrm{cm}^{3}\right)$ & $w_{0}(\%)$ & $p(\mathrm{kPa})$ \\
\hline 100 & $0.86-1.67$ & $1.95-42.0$ & $4-2560$ \\
\hline 50 & $1.24-1.84$ & $8.6-22.9$ & $14-960$ \\
\hline 30 & $1.50-2.30$ & 9.6 & $5-1280$ \\
\hline 20 & $1.45-1.58$ & $14.6-15.5$ & $0.9-1280$ \\
\hline 17 & $1.50-1.81$ & $5.0-5.6$ & $2.7-320$ \\
\hline 10 & $1.43-1.62$ & $3.1-4.1$ & $0.8-640$ \\
\hline
\end{tabular}

20\%，17\%，10\%の配合率の混合材においては, 表-2 の中から小さい垂直圧 $p$ のもとでの浸水試験結果だ けをプロットした (その理由は第 4 章で説明する). 図中のプロットは試験結果であり, 点線はそれぞれ の配合率のプロットにもっとも近くて平行になるよ うに引いたものである. 図-5より, (1)同じ配合率の 混合材においては両対数座標上で $\log e \sim \log p$ 関係が ほぼ一直線上で整理される. (2)異なる配合率の混合 材の間では $\log e \sim \log p$ 関係がほぼ平行している傾向 がある. (3)同じ垂直圧の場合では配合率が高いほど 浸水終了後の間隙比が大きい. 図-6 の浸水終了後の 含水比 $w$ と垂直圧 $p$ との関係も図-5 と同じ傾向を 示す.これは, 浸水終了後の供試体がいずれも飽和 度 $S_{r}=100 \%$ に達しているため, $e S_{r}=G_{s} w$ の関係式より 図-6 の縦軸 $w$ (含水比)は図-5 の縦軸 $e$ を $G s$ (比重) で割ったものになるからである. 図-6より, 同じ垂 直圧ではベントナイトの配合率が高いほど, よりた くさんの水を取り込んだと理解される.

\section{（4）モンモリロナイト間榢比 $e_{m}$ の定義および漫水終 了後の唯一的な $\log e_{m} \sim \log p$ 関係}

ベントナイトは主にモンモリロナイトが水を取 り込んで膨潤する. また, 図-3 中の $p=40,80,2560 \mathrm{kPa}$ での浸水試験結果より, 同じ垂直圧 $p$ のもとで単位 乾燥体積のモンモリロナイトが最も多く吸収できる 水の体積は初期乾燥密度に関係なく一定であること がわかった. そこで, ある垂直圧 $p$ のもとで単位乾 燥体積のモンモリロナイトが最大に吸収できる水の 量は一定であると考えられる. 本論文では, この浸 水変形後の水の体積とモンモリロナイトの乾燥体積 の比をモンモリロナイト間隙比 $e_{m}{ }^{10)}$ と呼ぶ. このモ ンモリロナイト間隙比は浸水終了後の含水比 $w_{2}$ あ るいは間隙比 $e_{2}$ とベントナイトの配合率を利用して 算出することができる.

具体的な式の誘導に入る前, 本論文で用いる記号 を羅列する.

$V_{m}:$ モンリロナイトの乾燥体積 
$V_{\text {sand }}:$ 砂の乾燥体積

$V_{n m}:$ 非膨潤性粘土鉱物の乾燥体積

$V_{v}:$ 間隙の体積

$V_{w}$ :浸水終了後の供試体中の水の体積

$m_{w}$ : 浸水終了後の供試体中の水の質量

$m_{m}:$ モンモリロナイトの乾燥質量

$m_{n m}:$ 非膨潤性粘土鉱物の乾燥質量

$m_{\text {sand }}:$ 砂の乾燥質量

$\rho_{w}:$ 水の密度

$\rho_{m}:$ モンモリロナイトの乾燥密度

$\rho_{n m}:$ 非膨潤性粘土鉱物の乾燥密度

$\rho_{\text {sand }}:$ 砂の乾燥密度

$\alpha:$ ベントナイトの配合率

$\beta$ :ベントナイト中のモンモリロナイト含有率

$M_{s}$ : 土粒子全体の乾燥質量 $\left(=m_{m}+m_{n m}+m_{\text {sand }}\right)$

$V_{s}$ : 土粒子全体の乾燥体積 $\left(=V_{m}+V_{n m}+V_{\text {sand }}\right)$

$\rho_{s}:$ 混合材の乾燥密度 $\left(=M_{\mathrm{s}} / V_{s}\right)$

$G_{s}:$ 混合材の比重 $\left(=\rho_{\mathrm{s}} / \rho_{\mathrm{w}}\right)$

モンモリロナイト間隙比 $e_{m}$ の定義より

$$
e_{m}=\frac{V_{w}}{V_{m}}=\frac{m_{w} / \rho_{w}}{m_{m} / \rho_{m}}=\frac{m_{w}}{m_{m}} \cdot \frac{\rho_{m}}{\rho_{w}}
$$

混合材において, モンモリロナイトの乾燥質量 $m_{m}$ はベントナイトの配合率 $\alpha$ およびモンモリロナイ 卜含有率 $\beta$ より式(3)で計算できる.

$$
m_{m}=M_{s} \alpha \beta 10^{-4}
$$

式 (3)を式 (2)に代入すると，モンモリロナイト間隙 比と浸水終了後の含水比との関係が次式で表される.

$$
e_{m}=\frac{m_{w}}{M_{s} \alpha \beta 10^{-4}} \frac{\rho_{m}}{\rho_{w}}=w_{2} \frac{\rho_{m}}{\alpha \beta \rho_{w}} 10^{2}
$$

ここに, $w_{2}$ は浸水終了後の含水比である.

$\rho_{m}$ および $\beta$ は表-1 に示すような試料の物理特性 であるので, 式 (4)より, 浸水終了後の含水比 $w_{2}$ と 配合率 $\alpha$ が分かれば, モンモリロナイト間隙比 $e_{m}$ を 算出することができる. また, 浸水終了後の飽和度 $S_{r}=100 \% よ り, e_{2} S_{r}=G_{s} w_{2}$ の関係を式 (4) に代入すると 式 (5)のモンモリロナイト間隙比 $e_{m}$ と浸水終了後の 間隙比 $e_{2}$ との関係が得られる。

$$
e_{m}=w_{2} \frac{\rho_{m}}{\alpha \beta \rho_{w}} 10^{2}=e_{2} \frac{\rho_{m}}{\rho_{s} \alpha \beta} 10^{4}
$$

式 (5)より, 浸水終了後の間隙比 $e_{2}$ と, 配合率 $\alpha$ が 分かれば, この時のモンモリロナイト間隙比 $e_{m}$ を算

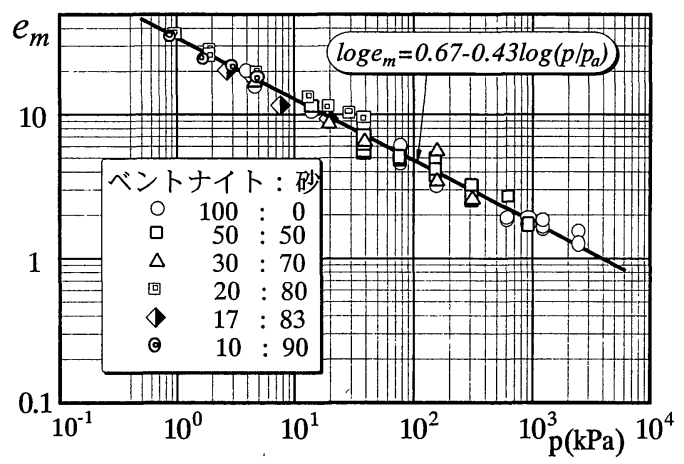

図-7 浸水終了後のモンモリロナイト間隙比 $e_{m}$ と 垂直圧 $p$ の関係

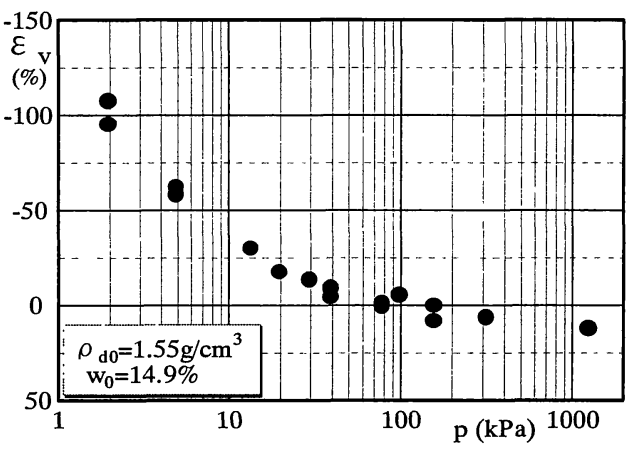

図-8 浸水による変形と垂直圧の関係

(ベントナイト : 砂 $=20 ： 80$ )

出することができる.

図-7 は，モンモリロナイト間隙比 $e_{m}$ と浸水終了 後の垂直圧 $p$ との関係を両対数座標上で整理したも のである (図中の近似式での $p_{a}$ は大気圧).ただし， 配合率が $30 \% ， 20 \% ， 17 \% ， 10 \%$ 混合材においては小 さい応力範囲での浸水試験結果のみをプロットした (図-5, 図-6 のデータと同じ). 同図より, 配合率に よらずに $\log e_{m} \sim \log p$ 関係が一直線上で唯一的に整 理されることが見られる. つまり, 同じ垂直圧の条 件下で, 単位乾燥体積のモンモリロナイトが最大に 取り込める水の量は一定であることである.そして, その量は垂直圧 $p$ が大きくなるにつれて少なくなる のが見られる.この唯一的な関係の状態線が成立す るとすれば, 同じ配合率のベントナイトの混合材に 対して, 垂直圧 $p$ を変えて 2 つ浸水試験を行い, 浸水終了後の含水比をそれぞれ測るだけで, 他の配 合率の混合材の, 浸水直前の状態からの浸水変形ひ ずみを予測することが可能となる. その具体的な予 測方法の流れを本文の最後に示す. ただし, 図-7に 示した唯一的な $\log e_{m} \sim \log p$ 直線関係を利用して, 低 配合率の混合材の浸水変形量を予測するには垂直圧 
により適用できない場合もある. 次節で, この適用 できない垂直圧の範囲について考察する.

\section{2. 低配合率の混合材において唯一的な $\log e_{m} \sim \log p$ 関係が適用できる応力範囲}

\section{（1）低配合率の混合材の浸水变形特性}

図-8 は, 配合率 $20 \%$ の混合材の浸水による膨潤ひ ずみ $\varepsilon_{v}$ と垂直圧 $p$ との関係を示したものである. 同 図より, 垂直圧 $p$ が約 $40 \mathrm{kPa}$ を超えると浸水による 変形は膨潤から圧縮に転じるのが見られる.つまり， 約 $40 \mathrm{kPa}$ より小さい垂直圧 $p$ の範囲では垂直圧が膨 潤圧より小さいため膨潤挙動を示すが, 約 $40 \mathrm{kPa}$ を 超えた垂直圧 $p$ の範囲では, 垂直圧が膨潤圧より大 きいため, サクションの減少とともに収縮挙動（コ ラプス）を示す.

図-9 は，配合率 $30 \% ， 20 \% ， 17 \% ， 10 \%$ の混合材に対 して異なる垂直圧 $p$ で浸水したすべての試験結果を 示したものである. 同図より, 小さい垂直圧 $p$ で浸 水した試験結果は唯一的な $\log e_{m} \sim \log p$ 直線関係上 に整理されるが，大きい垂直圧 $p$ での試験結果は直 線より上の方にプロットされているのが見られる.

また, 配合率が大きくなると, 直線上から外れる時 の垂直圧 $p$ も大きくなっているのが見られる．した がって, 配合率の異なる混合材において, 浸水終了 後の唯一的な $\log e_{m} \sim \log p$ 直線関係が成立する応力 （外部垂直圧 $p$ ）範囲は異なっている. つまり, 図 -7 に示した状態線の上の方から浸水してもこの状 態線までコラプス沈下しないということであるが, これは砂粒子の接触により形成した骨格が混合材の コラプス沈下変形を阻害したためと考えられる。

\section{（2）砂粒子の接触により形成された骨格が混合材 の浸水变形挙動に及ぼす影郬}

図-10 の概念図を用いて, 低配合率の混合材の浸 水変形特性のメカニズムを説明する. 配合率の高い ベントナイトの混合材 (図-10 (a) 参照) は, 浸水直前 の状態から膨潤しても，あるいはコラプスしても浸 水終了後には膨らんだモンモリロナイトが砂粒子を 挟んでいる形となり, 外部垂直圧を全部受け持つこ とになる (つまり $\left.p_{m}=p\right)$ ）この場合の試験結果は図 -7 に示した直線関係上にのると考えられる. しかし， 低配合率の混合材 (図-10 (b) 参照)においては砂粒 子の増加あるいは垂直圧の増加により, 砂粒子の間 で接触が生じ, 砂粒子の骨格が形成される. そのた め, 高い垂直圧では不飽和状態での圧縮線が図-10 （c）に示した状態線の上の方に位置する. この時, 垂

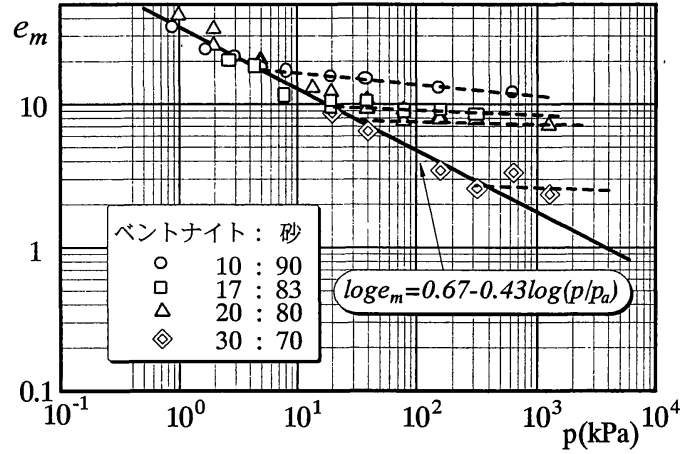

図-9 低配合率の混合材における浸水終了後の モンモリロナイト間隙比と垂直圧の関係

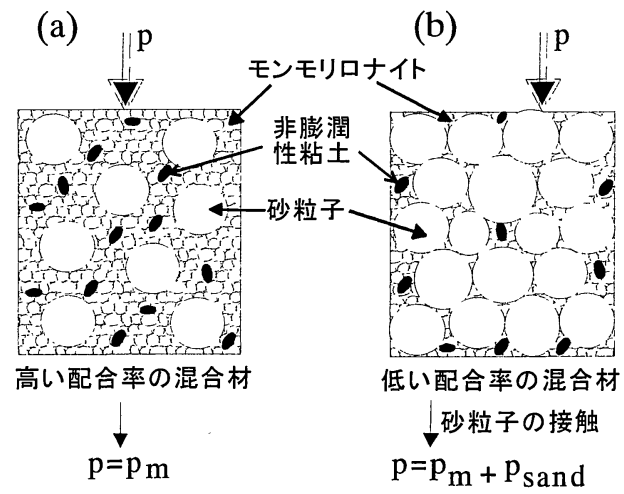

(c)

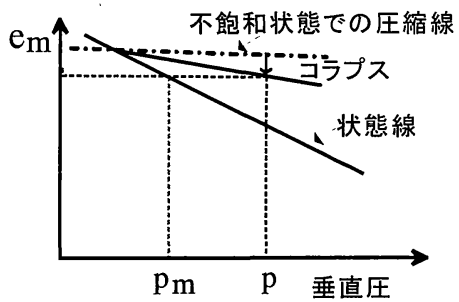

図-10 砂粒子の骨格の形成によるモンモリロナイト 間隙比への影響の概念図

直圧は膨潤圧より大きいため, 全体的にコラプスし ようとする傾向が強い。一方，砂粒子の接触により 形成した固い骨格は垂直圧のほとんどを分担し, 混 合材全体が体積圧縮することを阻害することになる. そのため, 浸水により土粒子の間のサクションが減 少すると, 少しの体積圧縮挙動を示す(図-8 参照)が, 図-10（c）の状態線までは収縮できない．この場合， モンモリロナイトが実際に受ける圧力は外部垂直圧 $p$ よりも小さくなる. このようにモンモリロナイト が小さい垂直圧の状態で浸水して膨潤した結果，よ 


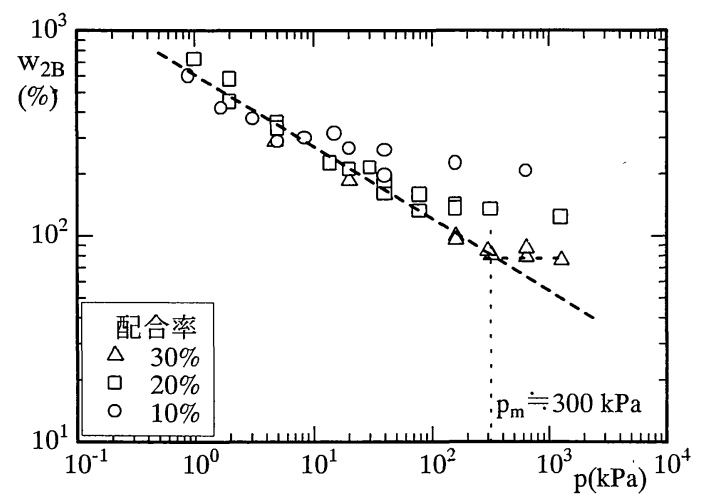

図-11 浸水終了後のベントナイト含水比 $w_{2 \mathrm{~B}}$ と垂直 圧 $p$ の関係

りたくさんの水を取り込んで砂粒子の間の間隙を 満たす形になったと考えられる. ただし，この場合 でもモンモリロナイト間隙比 $e_{m}$ と実際にモンモリ ロナイトが受けている $p_{m}$ (モンモリロナイトが発 揮する膨潤圧と理解してもいい) の関係は図-10 (c) に示すような状態線上にあると思われる.

\section{(3) 砂粒子の骨格が形成された条件下でのベントナ イトと砂粒子の間の間隙との関係}

混合材に対して, 浸水終了後のベントナイトの保 水状態を調べる目的で, 本節ではベントナイトの含 水比 $w_{2 B}$ というパラメーターを用いて検討する.

図-6 に示したように, ベントナイトが取り込め る水の量は垂直圧の大きさに依存する. そのため, 逆に浸水終了後のベントナイト含水比 $w_{2 B}$ がわかる と, ベントナイトがどれぐらいの垂直圧 $p$ を受けて いるのかも判断できる.

図-11 は配合率 $\alpha=30 \%, 20 \% ， 10 \% の$ 混合材にお いて, 浸水終了後の含水比 $w_{2}$ を配合率 $\alpha$ で割って求 めたベントナイト含水比 $w_{2 B}$ と垂直圧 $p$ との関係を 示す. $w_{2 B}$ を式で示すと式(6)のようになる.

$$
w_{2 B}=\frac{w_{2}}{\alpha 10^{-2}}=\frac{m_{w 2}}{M_{s} \alpha} 10^{4}=\frac{m_{w 2}}{m_{B}} 10^{2}
$$

ここに, $m_{w 2}$ は浸水終了後の供試体中の水の質量で あり, $M_{\mathrm{s}}$ は土粒子全体の乾燥質量, $m_{B}$ はベントナ イトの乾燥質量である.

図-11 より，垂直圧が増加するにつれてベントナ イト含水比 $w_{2 B}$ はだんだん小さくなる傾向が見られ る. そして, 砂粒子の接触が生じたと考えられる範 囲（破線より外れた領域）では，いずれの配合率の 混合材においてもベントナイト含水比 $w_{2 B}$ は小さい 垂直圧で浸水した時（砂粒子の骨格を形成していな

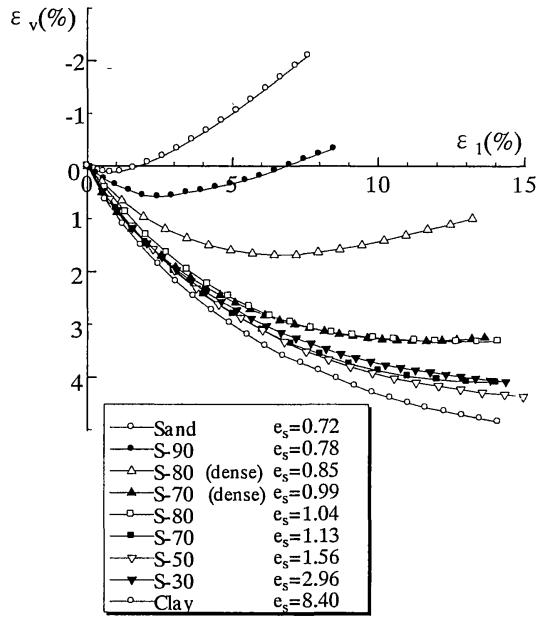

(a) 三軸圧縮時のダイレイタンシー特性と 骨格間隙比関係

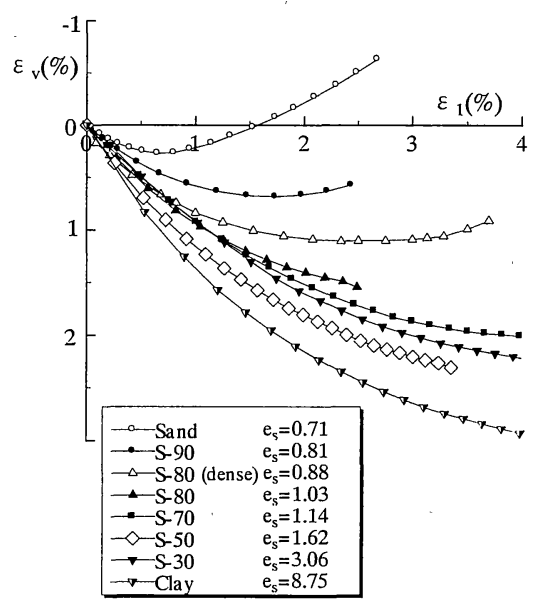

(b) 三軸伸張時のダイレイタンシー特性と 骨格間隙比関係

図-12 藤森粘土と豊浦砂との混合材のダイレイタンシと砂の骨格間隙比の関係

い時)の值 (例えば $p=0.9 \mathrm{kPa}$ 時の $w_{2 B}=700 \%$ )より小さ いことが見られる.このことは砂粒子の骨格を形成 しても, ベントナイトはもっと膨潤する能力がある ことあるいは,もっと水を取り込める能力があるこ とを意味している.したがって, 砂粒子の骨格が形成 されても垂直圧の一部はベントナイトが分担してい ることがわかる、ベントナイトが砂粒子の接触によ り形成した骨格の間の間隙を満たしていない限り垂 直圧を分担することはできない.したがって,ベント ナイトは図-10 (c) に示すように砂粒子の間の間隙を 全部満たして垂直圧の一部 $\left(p_{m}\right)$ を分担していると考 えられる.(このことは,低配合率の混合材が遮水材と してもふさわしいことを示している). 
（4）砂の骨格間隙比より低配合率の混合材の唯一的 な $\log e_{m} \sim \log p$ 関係の適用できる垂直圧範囲の推定

低配合率の混合材において, 唯一的な $\log e_{m} \sim \log p$ 直線関係が適用できる垂直圧の範囲を定めるため, 砂の骨格間隙比 $e_{s}$ を用いて検討する. 中間土によく 使われる砂の骨格間隙比の定義を式 (7)に示す.

$$
e_{s}=\frac{V_{\text {䟞以外 }}}{V_{\text {紧 }}}
$$

ここで, $V_{\text {砂 }}=V_{\text {sand }}, V_{\text {䟞以外 }}=V_{v}+V_{m}+V_{n m}$ である.

図-12 は, 藤の森粘土と豊浦砂との混合材を用い て行った平均主応力 $p=980 \mathrm{kPa}$ での三軸圧縮・三軸 伸張試験によるダイレイタンシ-挙動 ${ }^{11)}$ を示す. 同 図より,三軸圧縮・三軸伸張とも砂の骨格間隙比が 豊浦砂の最大間隙比 (約 $1.0^{12)}$ ) より小さい值でせん 断すると正のダイレイタンシ-を示すのが見られる. また, 砂の骨格間隙比が小さくなるにつれて体積膨 張する傾向も強まるのが見られる. 一方， $e_{s}$ が 1.0 より大きい值を示す中間土ではせん断中に負のダイ レイタンシーだけを示す.つまり, 砂の骨格間隙比が その砂の最大間隙比の值になると砂粒子の間で接触 し始め, 砂の骨格が形成されることを示していると 考えられる.

そこで，ある一定の配合率の混合材において砂粒 子が接触し始める時 (図-9 に示した唯一的な $\log e_{m} \sim$ $\log p$ 直線よりちょうど外れようとする時), 砂粒子の 骨格がまだ荷重を受けていないと仮定すると, 式(8) と式(9)の 2 つ関係式が成り立つ. すなわち, 両対 数座標上で, $\log e_{m} \sim \log p$ の直線関係と砂の骨格間隙 比 $e_{s}$ 砂の最大間隙比 $e_{\max }$ という 2 つの関係が同時に 成り立つということである.

$$
\begin{aligned}
\log e_{m} & =a+b \log \left(p / p_{a}\right) \\
e_{s} & =e_{\max }
\end{aligned}
$$

ここで, $p_{a}$ は大気圧である.

ベントナイトと砂の混合材において砂の骨格間隙 比 $e_{s}$ の定義は次式で表される.

$$
e_{s}=\frac{V_{v}+V_{m}+V_{n m}}{V_{\text {sand }}}
$$

浸水終了後の飽和度が 100\%であることから

$$
V_{v}=V_{w}
$$

式(11)を式(10)に代入して,さらに式 (2)の水の体 積 $V_{\mathrm{w}}$ を代入すると, 式(12)が得られる.
式(10)より, $e_{s}=\frac{V_{v}+V_{m}+V_{n m}}{V_{\text {sand }}}=\frac{V_{m} e_{m}+V_{m}+V_{n m}}{V_{\text {sand }}}$

上の式より,$\quad e_{m}=\frac{e_{s} V_{\text {sand }}-V_{m}-V_{n m}}{V_{m}}$

$$
e_{m}=A e_{s}+B
$$

$$
A=\frac{V_{\text {sand }}}{V_{m}}=\frac{\frac{M_{s}(1-\alpha / 100)}{\rho_{\text {sand }}}}{\frac{M_{s} \alpha \beta 10^{-4}}{\rho_{m}}}=\frac{\rho_{\mathrm{m}}(1-\alpha / 100)}{\rho_{\text {sand }} \alpha \beta 10^{-4}}
$$

$$
\begin{aligned}
& B=-\frac{V_{m}+V_{n m}}{V_{m}}=-\left(1+\frac{\frac{M_{s} \alpha(100-\beta)}{\rho_{n m}}}{\frac{M_{s} \alpha \beta}{\rho_{m}}}\right) \\
& =-\left(1+\frac{\rho_{m}(100-\beta)}{\rho_{n m} \beta}\right)
\end{aligned}
$$

式(13) と式(14)に下記の 3 式を用いた

$$
\begin{aligned}
& m_{m}=M_{s} \alpha \beta 10^{-4} \\
& m_{n m}=M_{s} \alpha(1-\beta / 100) 10^{-2} \\
& m_{\text {sand }}=M_{s}(1-\alpha / 100)
\end{aligned}
$$

式(13)と式(14)より， $A$ および $B$ は配合率 $\alpha$ とべ ントナイト中のモンモリロナイト含有率 $\beta$ により 定まるパラメーターであり, 同じ配合率の混合材に おいては定数である. そのため, 同配合率の混合材 において, 浸水終了後のモンモリロナイト間隙比 $e_{m}$ と砂の骨格間隙比 $e_{s}$ の間に式 (12)に示すような線形 関係が成り立つ.

式(12)を式(8)に代入すると式(15)吕得られる.

$$
\log \left(A e_{s}+B\right)=a+b \log \left(p / p_{a}\right)
$$

上に述べた砂粒子が接触し始める時, 式 (8) と式 (9) が同時に成り立つことより, 式 (9)を式(15)に代入す ると式(16)が得られる.この式は，ある一定の配合 率の混合材が唯一的な $\log e_{\mathrm{m}} \sim \log p$ 直線より外れし 始める時の垂直圧 $p$ を求める式である. つまり, 式 (16) で求めた垂直圧 $p$ より小さい垂直圧範囲では浸 水終了後のモンモリロナイト間隙比が唯一的 $\log e_{m}$ 〜 $\log p$ 直線上にのるが, この応力を超える垂直圧下 では $\log e_{m} \sim \log p$ 直線から外れることを意味する.

$$
\log \left(p / p_{a}\right)=\frac{1}{b}\left[\log \left(e_{\max } A+B\right)-a\right]
$$




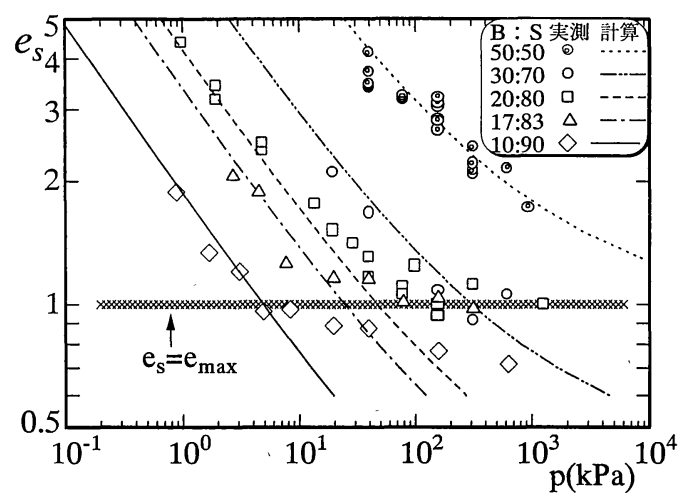

図-13 浸水終了後の砂の骨格間隙比と垂直圧の関係

図-13 は, 各配合率のベントナイトの混合材におい $\tau$, 浸水終了後の砂の骨格間隙比 $e_{s}$ と垂直圧 $p$ との 関係を示すものである. 図中の B と S はそれぞれべ ントナイトと砂を意味する．同図には，図-9 に示し たプロット $(30 \%, 20 \%, 17 \%, 10 \%)$ と $50 \%$ 混合材の 浸水試験結果を砂の骨格間隙比 $e_{s}$ で整理して示した. また，同図中の配合率ごとに示した線は式(15) に基 づいて計算した.

式 (8) は図-7 あるいは図-9に示した唯一的な直線 関係を示すが,これを砂の骨格間隙比で整理すると， 各配合率の混合材において, 浸水終了後の砂の骨格 間隙比 $e_{s}$ と垂直圧 $p$ との関係を示す式 (15) になる. 式(15)において, $A$ は配合率 $\alpha$ とベントナイト中の モンモリロナイト含有率 $\beta$ により定まるパラメー ターであり, 同じ配合率では定数である(式 (13) 参 照). $B$ はベントナイト中のモンモリロナイト含有率 $\beta$ だけに関係するパラメーターであり配合率 $\alpha$ と は関係ない（式(14)参照). そして $a$ と $b$ は図-7に 示した両対数座標上での直線関係の近似式より $a=0.67, b=-0.43$ となる. したがって, 式(15)は, 図-7 の直線関係が成立する場合, 各配合率の混合材 において, 浸水終了後に成立すべき砂の骨格間隙比 $e_{s}$ と垂直圧 $p$ の関係(図-13 中の各線)を示す.

図-13 より, 同じ配合率の混合材において, 小さ い垂直圧の範囲では $\log e_{s} \sim \log p$ 関係がほぼ各線上に のるが，垂直圧が大きくなると各線より外れるのが 見られる。 また, 配合率が大きくなると外れる時の 垂直圧 $p$ も大きくなることが見られる．つまり，図 -9 で示された現象が図-13 よりも再現されている. ただし，図-13 では各線から外れた時の砂の骨格間 隙比が $e_{\text {max }}(=1.0)$ より小さいことが見られる.この ことは, 混合材の中で砂粒子の密度が, 砂粒子の接 触し始める時の密度 (砂の最大間隙比 $e_{\text {max }}$ の時)より も大きいので, 砂粒子の接触が生じたことを示す.

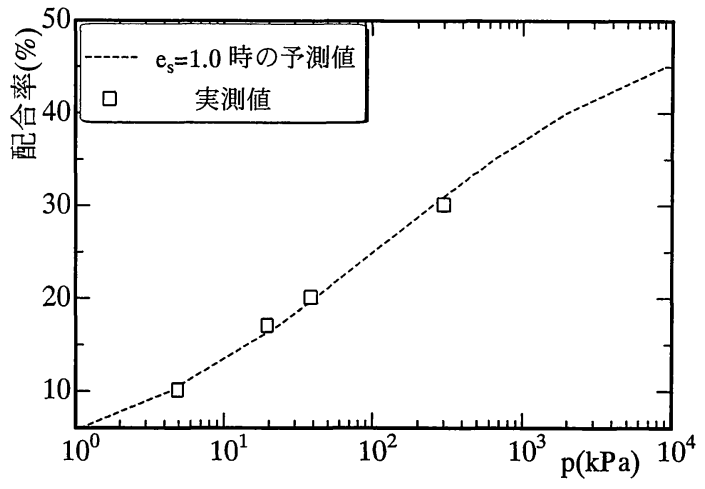

図-14 低配合率の混合材において砂の骨格が形成し始 める垂直圧

また，図-13より，30\%，20\%，17\%，10\%の混合材 のプロットは, 砂の骨格間隙比 $e_{s}$ が約 1.0 になると ころから各線より外れるので, 砂の骨格間隙比がこ の值になると砂の骨格を形成し始めると考えられる. したがって, 各配合率の混合材において式(15)の適 用範囲は砂の骨格間隙比がその砂の最大間隙比 $e_{\text {max }}$ より大きい時であることがわかった.

同図中の 50\%の混合材においては, 示した応力範 囲内ではこのような現象が見られない.これは $50 \%$ の混合材においては，この応力範囲内で砂粒子の骨 格を形成していないことを示している.

図-14 は，各種配合率の混合材が図-9に示した唯 一の $\log e_{m} \sim \log p$ の直線関係から外れ始める時の垂 直圧を示す．予測値 (破線) は式(16)に基づいて計算 した. この場合, 式(16)において, $\mathrm{e}_{\max }=1.0$ であり, $\beta$ は定数であるため, この式は垂直圧 $p$ と配合率 $\alpha$ の関数になる. 同図より, 予測值が実測值をよく説 明している.

また, 混合材において, 砂粒子が接触し始める時 のモンモリロナイト間隙比 $e_{m}$ が負にはならない（間 隙体積が負にならない）という条件より, 次の 2 式 が成り立つ.

$$
\begin{gathered}
e_{s}=e_{\max }=1.0 \\
e_{m} \geq 0
\end{gathered}
$$

これらの式を式 (12)に代入すると, 次の関係式が得 られる.

$$
1.0 A+B \geq 0
$$

式(13) と式(14)を式(19)に代入し, 表-1 に示したパ ラメーターを用いて解くと, 式(20)が得られる.

$$
\alpha \leq 51.1 \%
$$




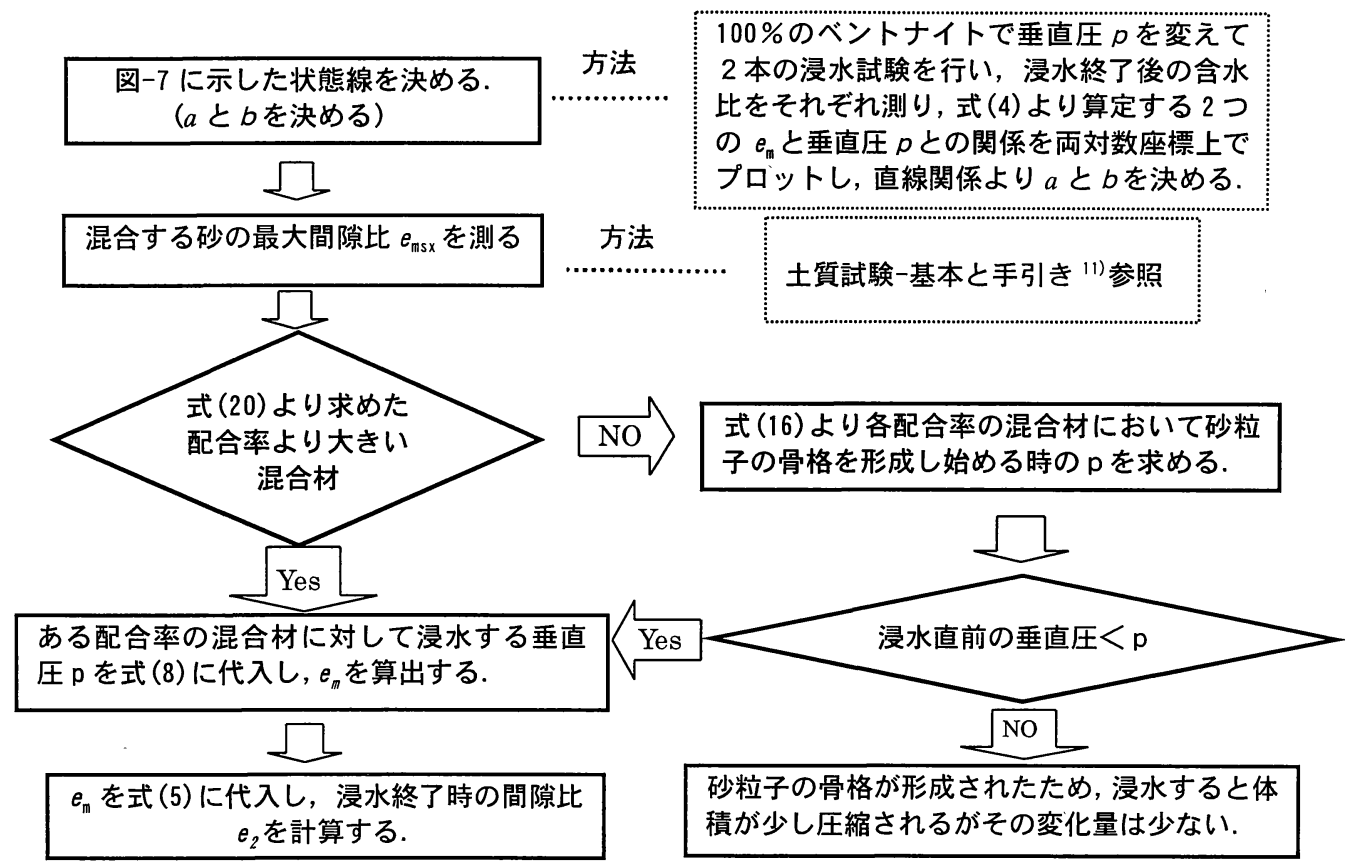

図-15 浸水終了後の間隙比を予測する流れ

つまり, ベントナイトと豊浦砂の混合材において, 配合率 $\alpha$ が $51.1 \%$ 超えると砂粒子の接触が起こら ないこと, あるいは $51.1 \%$ 超える混合材において は図-7 に示した唯一的な $\log e_{\mathrm{m}} \sim \log p$ 関係がすべて の垂直圧の範囲内で成り立つことを意味する. 図-13 より, $50 \%$ の混合材 $(B: S=50: 50)$ においては, 示 した応力範囲内で砂の骨格間隙比が 1.0 以上になっ ているのが見られ，上述の考え方が正しいことが検 証された.

以上の考察より, ベントナイトと砂との混合材の 浸水終了後の間隙比の予測方法のフローチャートを 図-15 に示す.

\section{5. まとめ}

本研究より得られた結論を以下にまとめる.

(1) 締固めたベントナイトと砂との混合材は浸水さ れると, 密度, 含水比および浸水直前の垂直圧に よって膨潤あるいはコラプス挙動を示す。

(2) 同じ配合率の混合材 (配合率が約 51\%を超える混 合材)においては, 浸水により膨潤してもコラプス しても浸水終了後の間隙比と垂直圧は一本の $\log e \sim \log p$ 直線上で整理される.

(3)ベントナイトの浸水膨潤は, 主にモンモリロナイ
トの吸水によるものであるため, 浸水終了後のモ ンモリロナイト間隙比 $e_{m}$ と垂直圧 $p$ との関係が配 合率に関係なく両対数座標上で唯一的な直線関係 に整理される.この線はモンモリロナイトの最大 の保水能力（純水の場合）と垂直圧の関係（ある いはモンモリロナイトの保水能力と膨潤圧の関 係）を示す状態線である.

（4）浸水直前の状態が状態線の下方に位置している 場合は, 浸水されると配合率に関係なく，この状 態線まで膨潤する. 一方, この状態線の上方より 浸水されると状態線までコラプス沈下する. ただ し, 低配合率の混合材の場合は砂粒子の骨格が形 成されるため, 状態線まで体積圧縮することがで きなくなり，モンモリロナイト間隙比と垂直圧の 関係が状態線より上方に位置する.

(5) 浸水直前の状態が状態線の上方に位置する場合 には 2 つのケースがある. (1) 初期含水比の低い 試料を用いて締固めて圧縮した場合である.この 場合, サクションが大きいため不飽和状態で不安 定な構造を形成する. (2)低配合率の混合材におい て，砂粒子が多いため; 不飽和状態で圧縮すると 砂粒子の間で接触し，固い砂の骨格を形成する場 合である.

（6）低配合率の混合材は, 図-7.に示した状態線の右 側まで不飽和状態で圧縮されて浸水すると, 膨潤 
することなく状態線まで収縮する傾向を示すが, 砂粒子の形成した骨格は収縮を阻害するため, 収 縮量が小さくなる. また, この時ベントナイトは膨 潤により, 砂粒子の間を充填するため, 水の経路の 形成を阻害できる. そして, 形成した砂の骨格はせ ん断強度の増加にも寄与すると思われる. したが って, 低配合率の混合材はいい遮水材となりうる.

(7) 砂の骨格間隙比がその砂の最大間隙比に近い值 になると砂粒子の骨格が形成される.

（8）低配合率の混合材において, 図-7に示した状態 線を利用して浸水変形量を予測するには垂直圧 の適用範囲が存在する. 本研究では砂の骨格間隙 比という概念を引用して, この適用範囲の定める 方法を提案・検証した.

(9) 配合率が約 51\%を超えるベントナイトと豊浦砂 の混合材においては砂粒子の骨格が形成されな い. したがって, 浸水終了後のモンモリロナイト 間隙比と外部垂直圧との間の唯一的な直線関係 はすべての垂直圧において成立する.

本研究はベントナイトと砂との混合材の一次元的 な浸水試験より得られた成果であるが, 実際の問題 では 3 次元的に浸水変形する場合が多いと考えられ る. 今後は横方向も膨潤できる試験装置を用いて, 異なる応力状態での浸水変形特性を解明する予定で ある.

\section{参考文献}

1) 核燃料サイクル開発機構 : わが国における高レベル放 射性廃棄物地層処分の技術的信頼性, 一地層処分研究開 発第 2 次取りまとめ-分冊 2, 地層処分の工学技術, 1999.

2) 小峯秀雄, 緒方信英 : ベンドナイト緩衝材・埋め戻し 材の透水特性之簡易評価法の提案,土木学会論文集, No.
708/III-59, pp.133-144, 2002.

3) Komine, H. and Ogata, N.: Experimental study on swelling characteristics of sand-bentonite mixture for nuclear waste disposal, Soils and Foundations, Vol.39, No.2, pp.83-97, 1999.

4) Mollins, L. H., Stewart, D. I. and Cousens, T. W.: Predicting the properties of Bentonite-sand mixtures, Clay Minerals Vol.31, pp.243-252, 1996.

5) Yong, R. N. and Warkentin, B. P. : 土質工学の基礎, 山 崎不二夫, 山田豊聡監訳, 鹿島出版社, 1972.

6) 近藤三二:おはなしべントナイト,(株)豊順洋 行, 1994.

7) Barden, L., McGown, A. and Collins, K.: The collapse mechanism in partly saturated soil, Engrg. Geol.7, pp.49-60, 1973.

8) Mitchell, J. K.: Fabric, structure, and proterty relationships, Fundamentals of Soil Behavior, John Wiley and Sons, New York, pp.222-252, 1976.

9) Fredlund, D. G.: Comparison of soil suction and onedimensional consolidation characteristics of a highly plastic clay, Nat. Res. Council Tech. Report No.245, Divsion. of Building Res., Ottawa, Ont., Canada, pp. 26, 1964.

10) Xu, Y. F., Sun, D. A., Matsuoka, H. and Cui, H. B.: Swelling characteristics of sand-bentonite mixture due to sucking of water, 第 36 回地盤工学研究発表会講演集, pp.221-222, 2001.

11) 孫 “徳安, 松岡 元, 成瀬浩之, 内田光彦: 密度之配 合割合の異なる砂と粘土の混合土の変形・強度特性, 第 33 回地盤工学研究発表会講演集, pp.687-688, 1998.

12）社団法人地盤工学会:土質試験-基本と手引き-, pp.60, 2001.

(2003.7.23 受付)

\title{
SWELLING CHARACTERISTICS OF SAND-BENTONITE MIXTURES UNDER ONE-DIMENSINONAL STRESS
}

\author{
Hongbin CUI, De'an SUN, Hajime MATSUOKA and Yongfu XU
}

\begin{abstract}
Based on the concept that the maximum water volume absorbed by unit volume of montmorillonite is constant, the swelling deformation of sand-bentonite mixtures is uniquely characterized using the void ratio of montmorillonite, which is defined by the ratio of water volume to montmorillonite volume. The relationship between the montmorillonite void ratio and overburden pressure at fully swelling is independent of the initial compaction condition and the sand-bentonite mixture ratio, and is a linear line in their log scale. When overburden pressure is large enough and/or the bentonite ratio of the mixture is small, the measured plots deviate from the line. A method for predicting the limited overburden pressure which is linearly correlated with the montmorillonite void ratio is proposed and verified using the concept of the skeleton void ratio.
\end{abstract}

